\title{
COMING TO NARRATIVE INQUIRY IN THE CONTEXTS OF OUR LIVES: A CONVERSATION ABOUT OUR WORK AS NARRATIVE INQUIRERS
}

\author{
DILMA MELLO \\ University Federal de Uberlândia \\ SHAUN MURPHY \\ University of Saskatchewan \\ D. JEAN CLANDININ \\ University of Alberta
}

ABSTRACT The text reports our experiences as narrative researchers to highlight aspects of narrative research that often create difficulties for new researchers in this relational form of research. We begin by reminding readers that narrative inquiry is the study of the experience understood in the narrative. Thus, we draw attention to narrative research as a phenomenon under study and methodology for the study. This by itself often creates confusion for those who are new to narrative inquiry. We highlight three particular tensions that often cause difficulties for researchers. Engaging at the beginning of the autobiographical narrative, shifting from field texts to research texts and conducting narrative investigations made purposive for personal, theoretical/practical and social justifications were the three tensions we selected. Drawing on ongoing and recently completed narrative investigations, Dilma, Shaun and Jean have made explicit the ways in which they have moved from interim field texts to final research texts.

Keywords: Narrative investigation. Research experiments. Research Conversation. Relational ethics.

\section{RESUMO INTRODUZINDO A INVESTIGAÇÃO NARRATIVA NOS CONTEXTOS DE NOSSAS VIDAS: UMA CONVERSA SOBRE NOSSO TRABALHO COMO INVESTIGADORES NARRATIVOS}

O texto relata nossas experiências como investigadores narrativos, para destacar aspectos que, frequentemente, criam dificuldades para aqueles que se iniciam nesta forma relacional de investigação. 
Começamos lembrando aos leitores que a investigação narrativa é o estudo da experiência entendida narrativamente. Dessa forma, chamamos a atenção para a investigação narrativa como um fenômeno de estudo e como metodologia de pesquisa. Isso por si só, já cria confusão para aqueles que são novos na investigação narrativa. Destacamos três tensões particulares que, normalmente, causam dificuldades para os pesquisadores. Engajando no início da narrativa autobiográfica, mudando de textos de campo para textos de pesquisa e conduzindo investigações narrativas tornadas propositais para justificativas pessoais, teóricas/práticas e sociais foram as três tensões que selecionamos. Baseando-se em investigações narrativas contínuas e recentemente concluídas, Dilma, Shaun e Jean Clandinin tornaram explícitas as maneiras como mudaram de textos de campo provisórios para textos finais de pesquisa.

Palavras-chave: Investigação narrativa. Experiências de investigação. Conversa sobre pesquisa. Ética relacional.

\section{RESUMEN INTRODUCIENDO LA INDAGACIÓN NARRATIVA EM LOS CONTEXOS DE NUESTRAS VIDAS: UNA CONVERSACIÓN SOBRE NUESTRO TRABAJO COMO INVESTIGADORES NARRATIVOS}

El texto relata nuestras experiencias como investigadores narrativos para destacar aspectos de la investigación narrativa que, frecuentemente, crean dificultades para nuevos investigadores en esta forma relacional de pesquisa. Comenzamos recordando a los lectores que la investigación narrativa es el estudio de la experiencia entendida de forma narrativa. De esta forma, llamamos la atención hacia la investigación narrativa como un fenómeno bajo estudio y como metodología para el estudio. Eso por sí solo, frecuentemente, crea confusión en aquellos que son nuevos en la investigación narrativa. Destacamos tres tensiones particulares que, por lo general, causan dificultades a los investigadores. Comprometiendo en el inicio de la narrativa autobiográfica, transformando los textos de campo en textos de investigación y conduciendo investigaciones narrativas tornadas propuestas de justificaciones personales, teóricas/prácticas y sociales fueron las tres tensiones que seleccionamos. Basándose en investigaciones narrativas continuas e recientemente concluidas, Dilma, Shaun e Jean tornaron explícitas las maneras de cómo transformaron los textos provisorios de campo en textos finales de investigación

Palabras clave: Investigación narrativa. Experiencias de investigación. Conversación sobre investigación. Ética relacional 
We three have engaged in narrative inquiry over many years now. We have each participated in several studies with teachers, youth, children, physicians, student teachers, student physicians, administrators, families, and university teachers. We have learned to work from the following definition of narrative inquiry.

Narrative inquiry is a way of understanding experience. It is a collaboration between researcher and participants over time, in a place or series of places, and in social interaction with milieus. An inquirer enters this matrix in the midst and progresses in the same spirit, concluding the inquiry still in the midst of living and telling, reliving and retelling, the stories of the experiences that make up people's lives, both individual and social. (CLANDININ \& CONNELLY, 2000, p. 20)

Narrative inquiry is the study of experience understood narratively. Attending carefully to the definition allows us to think about the layers of meaning in how we understand narrative inquiry. While the most important defining feature of narrative inquiry is that it is the study of experience as it is lived and told, it is more than this. It is more than telling stories, more than living stories.

Dewey's conception of experience underlies our understandings of narrative inquiry. We work from Dewey's conception of experience as "[...] a changing stream that is characterized by continuous interaction of human thought with our personal, social, and material environment [...]" (CLANDININ; ROSIEK, 2007, p. 39). Working with this conception of experience shapes the three-dimensional narrative inquiry space with its dimension of temporality (past, present, future), sociality (with attention to the personal and the unfolding existential events), and place (the topological geographic places where events including inquiry events take place) (CLANDININ; CONNELLY, 2000).

We have, in our studies over these many years, learned much about narrative inquiry, particularly about what it means to live relationally alongside others as we engage in narrative inquiry (CLANDININ, CAINE, STEEVES, 2013) and what it means to live at the borderlands with other research methodologies (CLANDININ; ROSIEK, 2007). What we have learned often draws our attention to the tensions that we live with as we engage in narrative inquiry.

\section{Living in the tensions of engaging in narrative inquiry}

What we mean by tensions is, perhaps, not what is usually meant by tensions, meaning, we do not see tensions as directing our attention to a problem to be solved or some-thing that can be fixed or changed or smoothed over. What we mean by tensions draws on the work of Clandinin et al. (2010). While tensions are often seen as having "[...] a negative valence, that is, tensions are something to be avoided or smoothed over [...]" (p.82), we understand tensions "[...] in a more relational way [...]" (p. 83). We see tensions as "[...] lived be-tween people, events, or things ... [in ways that shape] a space between [...]" (p. 83), a space with much potential for inquiry. Tensions draw our attention to the inquiry edges where we can learn most by staying awake to the bumping places, to places where we feel the dissonance, the uncertainty, the sense that something is not quite right, the places that call us to ask ourselves, what is happening here?

In this paper we outline three tensions that seem particularly relevant to our most recent work: the tensions around writing autobiographical narrative beginnings to situate our work, the tensions around moving from field texts to research texts, and the tensions around justifying each study in order to respond to the personal, practical, and theoretical justifications of each study. These tensions emerge in part from the design considerations of narrative inquiry. The design considerations 
are based on twelve touchstones of narrative inquiry (CLANDININ \& CAINE, 2012). In order to address the tensions we each draw on recent narrative inquiries we are involved with.

\section{Situating our research contexts}

Shaun: Currently I am conducting an inquiry into curriculum making in a rural school titled, Life in a rural school: A narrative inquiry into identity making and curriculum making in rural education. In this inquiry I am attending to the experiences of children, families, and teachers in the meeting of their lives in rural educational settings. My larger wonder is: How do experiences in and out of school shape curriculum making and identity making for children, families, and teachers? My interest arises from my own experiences as a rural child and experiences working in rural schools. A tension I hold in relation to this wonder is the role of attending to place when teaching in rural schools.

Jean: One of the studies in which I learned a great deal about tensions and about staying awake to my life and my research in relation with participants, as well as with the research landscape was a study alongside youth who left school prior to graduating (CLANDININ, CAINE, \& STEEVES, 2013). We shaped the research puzzle around the experiences of early school drop outs, including their stories of the part that school played in their stories of leaving as well as their stories of the part leaving school early, that is, without a certificate, had on their lives.

Dilma: My current work is mainly related to the teaching landscape for students with some special need, specifically, visually challenged students (Blind and/or Low vision). I am particularly interested in the relational experience between teachers, and students, I also consider the school context, the milieu. As a narrative inquirer and also as a grandmother of a boy with low vision I thought it would be easier for me to carry out this inquiry and to write my narrative beginnings. However, I was surprised by the tension I experienced while writing my narrative beginnings.

Tension 1: Writing narrative beginnings: Engaging in autobiographical narrative inquiries at the outset and throughout the narrative inquiry

Engaging in autobiographical narrative inquiry is very much part of any narrative inquiry. It is not easy work but it is important that we begin each narrative inquiry with this task. As Clandinin $(2013$, p. 36$)$ wrote,

Firstly, it is important to inquire into who you see yourself as being, and becom-ing, within the inquiry. Without an understanding of what brings each of us to our research puzzles, we run the risk of entering into relationships without a sense of what stories we are living and telling in the research relationships, and in the ways we attend to the experiences of research participants.

Noting that such work is part of narrative inquiry does not mean that it is easy work. This ongoing self-reflexive or self-facing work requires that we attend carefully to who we are in the world and to how we have shaped the world in which we live our lives (CLANDININ \& CONNELLY, 2000).

\section{Shaun's narrative beginnings: a curriculum-making narrative inquiry}

Shaun recently made a move within his university from the department of Curriculum Studies to Educational Foundations and was in the midst of shaping a slightly altered academic identity in relation to his new department. Shaun had no intent of leaving his curriculum 
theory roots behind. He had been a mathematics teacher educator, but would no longer be teaching in the subject matter area. Shaun had always had an interest in rural teacher education. Acknowledging this interest felt right to him. He had been raised in a rural location, taught in rural schools, and was very interested in rural education for children, youth, and teachers. Shaun was involved in two previous narrative inquiries that shaped how he would engage in this research. An earlier inquiry was where he was part of a research team (CLANDININ, HUBER, HUBER, MURPHY, MURRAY ORR, PEARCE, \& STEEVES, 2001) inquiring into the experiences of children, teachers, and administrators in an urban elementary school. His most recent inquiry focused on the experiences of children, families, and teachers (CLANDININ, HUBER, MURPHY, MURRAY ORR, 2007) in an achievement-testing era. These two inquiries shaped his thinking about how curriculum is composed in relationships. In the latter study, we (HUBER, MURPHY, \& CLANDININ, 2011) developed the idea of familial curriculum making, in order to recognize the curriculum-making worlds of children and families. In his new inquiry Shaun was interested in the ways families, children, teachers, and administrators shaped curriculum-making experiences (CLANDININ \& CONNELLY, 1992) attentive to rural places. This inquiry was shaped in relation to place-based curriculum (AJAYI, 2014; AZANO, 2011, 2014; BROOK, 2013; GRUE-NEWALD \& SMITH, 2014; WAITE, 2013).

\section{A narrative beginning}

I was born in a small town and grew up on a farm. My parents both had professional careers in our small town. I always felt like I lived in two worlds. I wasn't really a farm kid, although it was a working farm, and I really wasn't a town kid, although we were very involved in town activities. I took the bus to school every- day in town and played and did chores on the farm every afternoon and weekend. I played in the woods, fields, and slough down the road. I knew I was always destined for university, for a life way from the farm. When I became a teacher I started my career in another small town. I worked in different places over time and spent the longest period of time at a school in the country, not even in a town around it. When I became a teacher educator I held onto my interest about teaching in rural places, but did not focus on it. When I was invited to work alongside children, teachers, families, and administrators in a small town I leapt at the chance. I am still trying to figure out what it means to teach in rural schools. I am still trying to figure out what rural actually means in the lives of people. I wonder about the ways attention to place-based education can support the learning of children and the teaching of teachers.

\section{Wonders about my narrative beginning}

My experience as a farm boy living in two worlds shapes who I am in my current inquiry. I know that my interest in this work stems from my beginnings on a farm outside a small town in rural northern Alberta (a province in Canada). I know that my interest in rural education stems from my childhood, teaching career in rural schools, research work on the worlds of children, and my thoughts about curriculum making. When I write papers I am aware that this shapes me and while I do not compose, within a paper, a narrative beginning, I often find that this is woven throughout the paper in ways that I hope shows the reader that I am connected to the work beyond just an academic interest. I have noted in the writing of students, in a recent course, that they think bias is a bad thing in research, but bias is a value neutral term and is always present in our work. It is something to attend to and 
it is worth noting that I have a personal bias towards rural education.

\section{Jean's narrative beginnings: the early school leaver narrative inquiry}

By the time that Jean engaged in the narrative inquiry with early school leavers, she had been shaped by several studies as well as by her experiences as a child in school, as a teacher and counselor in schools and by her work as a teacher educator. The wonders that evolved from earlier work shaped the early school leavers study. We (CLANDININ, HUBER, MURPHY, MURRAY ORR, PEARCE, \& STEEVES, 2002) had completed a narrative inquiry in one school alongside children, teachers and school administrators. We had also had conversations with some parents and family members. While the focus was on the ways that children's and teachers' identities are interwoven in schools we became aware that some of the children had begun to disengage from schools as early as the primary grades. In our last chapter in the book, we drew on Smyth and Hattam's (2004) study of school leavers and began to wonder about the experiences of youth who left school be-fore graduating. The wonders shaped in the study with the children and teachers at Ra-vine Elementary School stayed with us and we began to design a new study, a narrative inquiry in which we learned of the storied experiences of youth who left school prior to graduating.

We were reminded of the importance of inquiring into own stories of school, stories that shaped our assumptions, understandings, and experiences in and out of schools. This was important to us, as it helped us recognize reasons to engage in this work that grew out of our experiences, in and out of schools. While there were multiple starting points for the research such as previous narrative inquiries, re- search funding agencies and university ethical requirements, most importantly, each narrative inquirer began with an autobiographical narrative inquiry to help us understand more deeply who we each were in the research and what called us to the research. We began our autobiographical narrative inquiries in relation to who we each were in the research. Our purposes were less about the telling of our own stories in expansive ways and more about the ways that we entered the inquiry relationships, who we were and were becoming in relation with the youth who left school early as well as with who we were and were becoming in relation with stories of school.

In what follows I share segments of a word image representation of some of my narrative beginnings shaped into four temporal sections: early landscapes, high school graduation, becoming a teacher, and becoming a narrative inquirer. I share a fragment from each section:

I. Early landscapes.

The tensions and contradictions

lived each day, each week, each month.

Leaving one world

entering another world.

Each day

each week

each year.

II. High school graduation.

No family stories of graduation.

Stories of composing a life as a farmer's wife marriage, children

a life on a farm

hard work, not enough things, too much work the intergenerational patterns.

III. Becoming a teacher.

Becoming a teacher teachers belong in schools.

Leaving one world entering another. Living always the embodied memories of living in two worlds each day, each week, each year. 
IV. Becoming a narrative inquirer.

Complexities

lived over time

lived in multiple places

in multiple relationships

of what it means to know multiple worlds

of children and families

who are seen as other

whose stories don't fit

the dominant plotlines. (CLANDININ, CAINE, STEEVES, 2013, pp 7-10)

These stories were not easy ones for me to write nor are they easy to share with others. By easy I draw attention to how they were stories I had not written before and they were stories that I had not opened up to narrative inquiry. While I had told them I had mostly told them to myself, saying them as I worried my way into new studies. I had not made them public except in safe places on professional knowledge landscapes (CLANDININ \& CONNELLY, 1995), places where I could make myself vulnerable in order to learn from the tensions that I was experiencing. By writing them and narratively inquiring into them, they allowed me to position myself in the larger study of the experiences of youth who left school early as well as to position myself in relation to the two youth participants that I came alongside in the study.

\section{Dilma's narrative beginnings:}

\section{teaching and living in relation with people with special needs}

As soon as Dilma decided to carry out an inquiry on the experiences of teaching visually challenged students, she thought her narrative beginnings could be related to her own practice as a teacher when she had to be in relation with visually challenged students. She was reminded of a child she had taught some years before while working for a small college. Imagining that it was her first experience in relation with people with special needs, Dilma tried a narrative beginning.

Some years ago, as a teacher, I planned my class thinking of my students wishing they could learn easily. I prepared slides with words in different colors... verbs in black, adjectives in red, nouns in yellow, cognates in blue, and so on. Everybody seemed to be so attentive and satisfied but after the end of the class a boy came and told me he could not understand the differences based on the colors. He was a colorblind person. And despite my worries concerning inclusion I recognized I was very far from being aware of some differences.

As soon as Dilma finished part of her first tentative narrative beginning, she shared the piece with some other teachers who were also working on narrative beginnings. While reading her story to the group she soon realized that experience had not been her first experience in relation with people with special needs and she remembered another situation she had lived when she was an undergrad student. She finally thought she had found her beginning story and that her undergrad story would help her to discuss how and when she woke up for differences.

On the way home from my University, I came across a girl in the bus. She was deaf and could not speak using her voice as we do. I did not know the reason why she decided to "talk" to me. She touched me and insisted in having a conversation. I ignored her because I could not use her language. Soon I realized I was the challenged one in the situation. From that moment on I decided I would build language bridges. My sense was that I needed to be able to use different ways of communicating.

Again Dilma realized it was not the first situation in which she had been in relation with different people and another experience came to her, her brother went blind for a year during their childhood in Brazil. She wondered how 
could she not be aware, in relation to her research puzzle, of that part of her family story related to difference. This time she (re)started her narrative beginnings with her experience of her brother's experience.

My brother went blind for a year when I was around five and he was seven. I did not understand the reason why it happened, but I used to help him to go to school. However, sometimes I was mean and made jokes about his situation. I remember once when I led him to a wall in front of our house. We both laughed and soon I took him home. Probably as a child I was trying to investigate this new situation. I was trying to understand what he was and was not able to make sense of. I was al-so wondering about my role in that experience as a sister of a blind boy. At that time we were told he needed vita$\min A$ and he had to eat a lot of carrots every day so he could see again. Eventually, after a long year his vision did return. This was my first experience with blindness.

My narrative beginnings ended up being written altogether because my three tentative narrative beginnings created an opportunity for me to realize my relational experiences with people with special needs were much more intense and frequent in my life than I had realized. I had planned to point to my lack of knowledge about inclusive educational contexts but I realized I knew much less than I imagined, and I had thought I knew much more. My tentative narrative beginnings showed me how blind I was to my "relation" with people with special needs, although I see now the frequency of my relationships. I only really woke up to teaching for different students when my grandson was born with his congenital low vision. My attention to student difference is mainly grounded in these three experiences.

\section{Tension 2: tensions from moving from field texts to research texts}

\section{Shaun}

In Shaun's narrative inquiry into curriculum making in a rural school he began with an open wonder about what children, families, teachers, community members, and ad-ministrators might experience in their curriculum making. He wanted the inquiry to be shaped, in part, by the interests of the people in the school. While he was clear about the curriculum making aspect of the research he was happy to let the school shape the possible focus of the research. What emerged was an interest in school gardening. Shaun began with conversations with the administrator, made field notes about experiences in the grade $5 / 6$ class as they learned about gardening, made a trip to a local seniors' complex with the children and teacher, helped build the actual garden space, talked to families (parents and grandparents), had conversations with children, collected artefacts from children and teachers, and took photographs throughout the process. The field texts com-posed began to shape research texts. The primary shapes of the research texts were a proposal for a conference, conference paper, and a follow up paper for publication. Shaun was taught by Jean, that conferences are never an end point for papers, but a place for refining the writing and seeking the input of others. Another important aspect of the writing of research texts is the involvement of the participants. The writing was shared with various people involved in the research and their wonders shaped further writing. It was important, as the research texts were written, to think about the field texts as ways to represent experience and how they were inquired into through the three-dimensional narrative inquiry space (CLANDININ \& CONNELLY, 2000) This space is bounded by the narrative commonplaces of sociality, temporality, and place (CONNELLY \& CLANDININ, 2006) and an inward and outward, back ward and forward atten- 
tion to the experience of the research and researcher. Clandinin and Connelly (2000) explained these four directions.

By inward, we mean toward the internal conditions such as feelings, hopes aesthet-ic reactions, and moral dispositions. By outward, we mean toward the existential conditions, that is, the environment. By backward and forward, we refer to tempo-rality past, present, and future. (p. 50)

\section{Jean}

In the narrative inquiry with the early school leavers we engaged in different interpretive moves from field texts to research texts. The first move involved working with-in the three-dimensional narrative inquiry space of temporality, sociality and place with the field texts for each participant. We pulled forward narrative threads, those narrative plotlines that we discerned about which participant's life could be told. We wove those narrative threads into an interim research text that we called a narrative account (CLANDININ \& CONNELLY, 2000). We drew on the field texts (transcripts, field notes, artifacts) and worked within the three-dimensional narrative inquiry space as we wrote these accounts.

We were mindful that it was participants' stories shared in relation with us that were being written in the narrative accounts. Because narrative inquiry is relational inquiry, we knew we were co-composing the narrative accounts with participants. While some participants were more involved in the processes of moving from field texts to re-search texts, we negotiated each narrative account with each participant with one exception. One youth had indicated that he wanted his story told but we were unable to contact him to negotiate the narrative account. We asked each participant to select a pseudonym for themselves. In the narrative accounts we described home com- munities and demographic information when it was important to the experiences of the participants. We did not name cities, towns, or schools in order to provide anonymity to participants. Occasionally when we did mention schools or places, we created pseudonyms for them.

As we moved from field texts to writing these interim research texts, that is, the narrative accounts, we formed works-in-progress groups, which allowed us to respond to each other's tentative interpretations in the narrative accounts. Throughout, we remained respectful of the whole lives of participants. We were mindful that our intention was not to dissect their lives but rather to offer a representation of their narratives of experience.

Our second interpretive move involved looking across the nineteen narrative accounts to discern narrative threads that echoed across the accounts. For the purpose of preparing a final research text for the funding agency, we worked collaboratively as an 11 member research team to look across the 19 narrative accounts and pulled forward six resonant threads or patterns that we discerned as we looked across the narrative accounts of the early school leavers.

\section{Dilma}

Alongside with my research participant we went for the telling and retelling of his own experiences at school and our conversations in which we were trying to figure out how could inclusive education be understood considering the perspective of the one with special needs. Together we tried to compose meaning of the experiences lived having in mind particularly the inward and outward moves related to narrative inquiry as proposed by Clandinin and Connelly (2000).

First of all we talked, and my participant shared experiences lived at school with teach- 
ers and classmates. I played the tutor in charge of creating a safe place for the participant to share his experiences and also in charge of answering some of the schools' requirements, and tentative talking to teachers about my participant concerns having in mind his experiences lived and shared through our conversation sessions. Secondly, we wrote some narratives and while composing them as field texts, the participant chose himself a pseudonym and as a researcher I honoured his choice. He also composed different narratives using photos he had taken at school and some poems he had written about his experience in the classroom. Finally I turned the field texts into research texts by writing some narrative accounts on the experiences lived and shared. Both of us came to understand my participant's stories bumped up with school ones in relation to who he was as a student and what his needs were. Those were some of the threads I could com-pose in relation with the participant while looking out for school context and both perspectives on Inclusive Education.

\section{Tension 3: tensions around}

\section{justifying our narrative inquiries personally, practically and socially}

We have written elsewhere about the need to imagine the end of the inquiry and how we will respond to the questions of 'so what?' and 'who cares?', questions all re-searchers need to answer (CLANDININ \& CONNELLY, 2000; CLANDININ, 2013). While frequently these questions are asked at the end of a research study, in narrative inquiry, it is at the outset of our narrative inquiries that we first meet the questions of so what and who cares, questions which draw us toward the need to justify our narrative inquiries in three ways: the personal, practical, and social/theoretical justifications.
In part the autobiographical narrative inquiry work and the close attention to the scholarly literature are ways of beginning to respond to these questions.

Considerations of personal justification draw us to understand more deeply why the inquiry matters to each of us. "Our research interests arise of our own narratives of experience and shape our narrative inquiry plotlines [...]" (CLANDININ \& CONNELLY, 2000, p 121). As we have noted in the section titled Tension 1, we know how difficult it is to engage in autobiographical narrative inquiry and to understand the complexity of under-standing who we are in the inquiry and, in so doing, come to understand our purposes and justifications for engaging in the inquiry. While we cannot engage in narrative inquiry without considerations of who we are and are becoming in the inquiry and what brings us to the inquiry, personal justifications of each narrative inquiry are not enough.

Considerations of practical justifications are also important as we think about how our work will be taken up by others in teaching, nursing, policy making, teacher education and so on. As we write about our studies in final research texts, questions of how we justify our work practically are particularly important. This too is often a difficult under-taking.

Considerations of personal and practical justifications are often not considered of importance to the scholarly literature. As Clandinin and Connelly (2000) wrote,

Although we encourage the justification of inquiry interest in personal terms, the norms of inquiry have it that people should only justify their inquiry in social terms [...]. We need to be prepared to write "l" as we make the transition from field texts to research texts. As we write "I," we need to convey a sense of social significance. (p. 122)

However, we note that it is crucial for all three kinds of justification to be in evidence 
in narrative inquiries, even if the personal justifications are sometimes not fully evident in public research texts.

\section{Shaun: justifying the narrative inquiry into rural education}

Considering the justifications I have for this research I see how who I am, who I will be, and how I want to be in relation with teacher education is shaped by my interest in rural education.

\section{Personal justifications}

I know that curriculum making attentive to place is important in the lives of children, families, and teachers. This understanding arises from my own experience in curriculum making with children. Rural schools are expected to follow a mandated provincial curriculum/ subject matter guide. Learning that is situated in the places of children and teachers lives is learning that recognizes how we are shaped by where we lived.

\section{Practical justifications}

This narrative inquiry specifically attends to the lives of children, families, and teachers in a rural school, and builds on past narrative inquires into lives in school, curriculum making, identity making, and life transitions. This research will be long term and attend in turn to specific contexts such as familial experiences in schools and homes, teachers' and children's curriculum and identity making, and the work of administrators in a small rural school. Just as our participants are always in the midst of their lives, the ongoing parade of experience, so are narrative inquires. Situated in relation to previous narrative inquires they also shape future narrative inquiries. Both the research and the methodology are shaped by our research.

\section{Social/Theoretical justifications}

I drew on Dewey's (1938) concepts of experience and Schwab's (1978) curriculum commonplaces of learner, teacher, subject, and milieu as I shaped this new inquiry. Connelly and Clandinin (1988) concept of curriculum making as occurring at the inter-section of teacher, learner, subject matter, and milieu further shaped my thinking. Along-side teachers over many years Clandinin and Connelly studied these intersections gradually developing narrative constructions of teachers' knowledge as "personal practical knowledge" (CONNELLY \& CLANDININ, 1988), teachers' contexts as "professional knowledge landscapes" (CLANDININ \& CONNEL$L Y, 1995)$, and teachers' identities as "stories to live by" (CONNELLY \& CLANDININ, 1999).

This current inquiry is shaped by understanding that a curriculum of lives is understood as a counter narrative to dominant social, cultural, institutional, and linguistic narratives shaping lives in schools. Rather than seeing curriculum as only mandated subject matter; teachers' and children's identities, their stories to live by, composed in classrooms and schools, are central in the negotiation of a curriculum of lives (CLANDININ et al, 2006). A further reconceptualization of curriculum making entailed the conceptualization of "familial curriculum making" as a way to understand children's and families' interactions as they composed their lives in home and community places (HUBER et al., 2011). This reconceptualization of curriculum making further showed that children, and their families, experience many tensions as they daily travel to, from, within, and between the worlds of familial curriculum making and school curriculum making. Employing these understandings in my current inquiry will assist me to consider how this might be under-stood in relation to rural education attentive to place-based curriculum making. 


\section{Jean: justifying the narrative inquiry with early school leavers}

As I justify the narrative inquiry into the experiences of early school leavers, I realize now that I have been shaped by the experiences of participating in the inquiry alongside the youth. Who I am now, and who I am becoming, that is, my stories to live by, have shifted through the narrative inquiry with the young people who left school be-fore graduating.

\section{Personal justifications}

As I inquired into my experiences, I made visible my knowing of two worlds, the world of school and the world of home. I draw on Lugones (1987) work when I speak of worlds. Living in two such different worlds made the tensions and contradictions visible to me from early on in my life. Moving between my worlds of home and school, I made visible that, for me, the world of school was a place of dis/ ease for those who do not fit in, do not easily belong in schools where the plotlines are differentiated not only by grades and achievement but also by access to clothing, food, and material goods. Finding success defined in the dominant school narratives was not privileged in my familial narratives, my world of home. High school completion was a choice, not an expectation. My stories to live by were composed between worlds, valuing both the home and school worlds, choosing to teach, but always knowing that children and families lived in both worlds, that the worlds each person inhabited could be shaped by radically different plot lines. (CLANDININ, CAINE, \& STEEVES, 2013).

\section{Practical justifications}

Awakening to how constrained the narratives are for some youth and how difficult it is for some youth to live easily within the dominant stories of school was part of how I came to justify the narrative inquiry with early school leavers. I began to see that it was difficult for many to even see, or imagine, the complexities of the youth's lives, and worlds they live within. I came to understand the importance of attending to how the gaze from within stories of school too often makes invisible the lives of youth and families whose stories do not fit dominant plotlines. By engaging in the narrative inquiry alongside the youth who left school early, I came to see the importance of recognizing and attending to the experiences of the youth who struggle to be recognized, to be seen.

\section{Social/theoretical justifications}

Clandinin, Caine, and Steeves (2013) have written elsewhere about the social and theoretical justifications of the work with the early school leavers. They wrote,

We came to understand much about the need to pay attention to transitions. We were troubled by common views of transition and how these notions focus our attention in schools, in policies and procedures affecting youth. Focusing on the event of transition obscures our view of youth living in and through transitions. Narrative understandings of stories to live by as always in motion, open to shifting and changing, drew us to reconsider the life composing of youth who left school early, a transition out of school. Through attending carefully to the lives of the youth our understandings shifted in ways coherent with a narrative conceptualization of transition. We came to understand in more complex ways how stories to live by are shaped by, and are shaped in, embodied moments of transition.

As we attended to the lives of the youth as they became visible in the youths' told stories, we attended both to what they knew, and to the contexts or knowledge landscapes within which they lived in schools and outside of schools. As the institutional knowledge landscapes offered them fewer and fewer possibilities for continuing to compose their life identities, their stories 
to live by, they did not freeze. They drew upon their embodied knowledge composed over years and in multiple other contexts and relationships to shift their stories to live by. Awakening to different plotlines that shaped their knowledge landscapes, they improvised ways to make sense of their lives. Sometimes they chose to move schools, or to leave schools for a short time, or to shift from some relationships to other relationships. They made these shifts attentive to always searching for ways to make sense of their stories to live by that linked their knowledge and their storied contexts. Bound within multiple storied landscapes, the youth showed us how they improvised something new that allowed them to move forward, to keep at life composing within schools, to keep trying to make school work for them until their only possible way to achieve narrative coherence was to leave school. (CLANDININ, CAINE, \& STEEVES, 2013, p. 327)

\section{Dilma: justifying inquiries into}

\section{the experiences of students with special needs}

\section{Personal justifications}

As indicated in the first part of this paper, I started my current work addressing my attention to the inclusive educational landscape for students with special needs, focusing on people who were low vision challenged. However, as I began to write my initial stories it became clear to me that as a teacher I needed to begin with myself and my own experiences alongside my students and family members. Then my grandson was born with congenital low vision caused by macular degeneration, and later I developed low vision. My lived experience completely changed the way I conceived inclusive education. For personal reasons I needed and felt I had to carry out studies on Inclusive Education considering the perspective of those often excluded. After experiencing many difficult experiences with my grandson at school, and with myself at work, I decided it was time for me to bring those experiences into my professional life as a narrative inquirer, after all, life and education are two way paths and one learns considering both aspects, as suggested by Dewey (1938: 1997).

\section{Practical justifications}

My practical justification is very related to my personal justification. I could not solely be a narrative inquirer who carries out inquiries on inclusive education without considering tensions related to the landscape of teaching as a teacher educator. I was and I am willing to try to understand this path and to create conditions for my undergraduate and graduate students, my colleagues at the University, who I work with, to become aware of this world of differences. Schools and students from all levels deserve different teaching attentive to diversity.

There are also so many families in Brazil, my home country, trying to understand their children with disabilities so as to help them. I wonder if my teacher education work could be of some help for them. Children go to school and all deserve to learn. I try to help undergraduate and graduate teachers to know there are many different perspectives of being understood and of understanding education and life.

\section{Social justification}

Once again I see how my social justification is closely interconnected with my personal and practical justifications. Academic thinking is generally conducted through objective lenses and as a result an autobiographical inquiry or an inquiry in which one has a relative as a participant may sometimes be misunderstood or not very well considered. Murphy, Huber, and Clandinin (2012) share and discuss their view on curriculum attending to two worlds of curriculum making. They understand that cur- 
riculum is made and lived in familial or home contexts and another curriculum-making world is constructed and lived at school. The authors note it is important to pay attention to what happens in between both worlds and the movement and negotiation for children as they travel between these two worlds. Attending to these two worlds as a narrative inquirer I socially justify my research by considering that there are many investigations carried out concerning curriculum at school but not many attentive to curriculum made lived at home among family members.

I further situate my social justification and the need to inquire into inclusive education is by taking into consideration the work of Lugones (1987) regarding world travel-ling and the perceptions that shape how we understand and view those worlds. Lugones (1987) wrote that there are two perceptions we can bring to our attention to different worlds, arrogant and loving perception. Inclusive education has been mainly investigated by looking at the challenged from the position and perspective of an outsider. I was and still am very interested in trying to be aware and understand other possible perspectives.

Finally, I will plan and carry out my inquiry trying to understand different ways of belonging to school classrooms while dealing with differences. My reading of Wenger (2001) who proposes classroom can be lived as a community of learning and practice, meaning that learning is a lived experience negotiated on school landscapes (CLANDININ \& CONNELLY, 1995).

Before we move into our concluding thoughts we want to stress the importance of our ethical responsibilities in a narrative inquiry. These responsibilities are one of the most salient aspects of our research and shape our inquiries from beginning to end.
Ethical responsibilities: the relational ethics of engaging in narrative inquiry

While not discussed in previous sections of this paper, there is a sense in our consideration of narrative beginnings, the shift from field texts to research texts, and the justifications that shape an inquiry of the centrality of the relationship between the participants and the researcher. We have shown how our inquiries emerge from our own experience in relationship with others, how our field texts shape research texts in relationship with participants, and how our justifications are situated in relationship with methodology, theoretical work, and most importantly people. "Relationship is the key to what it is that narrative inquirers doing" (CLANDININ \& CONNELLY, 2000, p. 189).

The importance of relationship shapes an ethical response that goes beyond the ethics process we must engage in at our universities and attends to the obligations we have to the people with whom we work in an inquiry. Ethical matters are central through-out a narrative inquiry and while they may change and shift "they are never far from the heart of our inquiries no matter where we are in the inquiry process" (CLANDININ \& CON-NELLY, 2000, p. 170). Clandinin and Connelly (1988) wrote of the ongoing negotiation of the narratives of experiences carried within researchers and participants involved in the inquiry, the "negotiation of two people's narrative unities" (p. 281). For them, "this was a deep experiential process that lives at the heart of the relationships the researcher and participant negotiate. In this way, the narratives of their experiences shape the inquiry" (CLANDININ, CAINE, \& STEEVES, 2013, p. 64) Ethical obligations are the most pressing aspect of a narrative inquiry. 


\section{Concluding thoughts}

We began this paper with the intention of using our experiences as narrative inquirers to highlight aspects of narrative inquiry that often create difficulties for those new to this relational form of research. We began by reminding readers that narrative inquiry is the study of experience understood narratively. In this we draw attention to narrative inquiry as both phenomenon under study and methodology for the study. This in itself often creates confusion for those new to narrative inquiry. We also wanted to highlight that there are multiple tensions in engaging in narrative inquiry. We pulled forward three particular tensions that frequently cause difficulties for researchers. Engaging in autobiographical narrative beginnings, moving from field texts to research texts, and conducting narrative inquiries made purposeful by personal, theoretical/practical, and social justifications were the three we selected.

Narrative beginnings are foundational to engaging in narrative inquiry and the experiences that shape each person's different narrative inquiries need to be undertaken with each new narrative inquiry. As Dilma illustrated there are many experiences we can draw from to write our narrative beginnings in an inquiry, she aptly demonstrated the complexity of situating her work in relation to her experiences in her unfolding living. She wrote of many experiences that shaped her ways of thinking about her narrative inquiry into educational inclusion. As she considered why she was interested in and what understandings she brought to her narrative inquiry she attended to her work as a teacher, her interactions in public places, her familial connections, and her personal experience of low vision. Jean brought an understanding of the complexity of her experiences as she composed her stories to live by as she lived within the worlds of school and home and as she moved between these two worlds. Shaun narrated his experience as a boy living in a rural setting and his teaching experiences across his career that shaped a deep interest in rural education.

Researchers new to narrative inquiry often experience tensions as they struggle to understand moving from being in the field, to co-composing field texts, and to composing interim and final research texts (CLANDININ \& CONNELLY, 2000). Drawing on recently completed and ongoing narrative inquiries, Shaun, Dilma, and Jean made explicit the ways they moved from field texts to interim and final research texts.

The third set of tensions involved the need to justify narrative inquiries, justifications that are shaped by questions of meaning and social significance. These justifications call narrative inquirers to see the ways that their studies contribute to the larger conversations and dialogues in social science research. Again drawing on Dilma, Shaun, and Jean's experiences, we highlight how we have justified narrative inquiries in recent studies.

The personal is situated in relation to a researcher's narrative beginnings and made clearer in the unpacking of such beginnings. In this way we show, as narrative inquirers, what we bring to this research and how we are positioned to undertake our inquiries. In the personal justification we inquire into our own knowing and consider how this knowing helps us in the inquiry. Often it is a way of locating our passion for the topic under study.

A practical justification often brings us close to the experiences of others and the social contexts in which they are positioned. Here we often ask questions about teaching, care, or social practices. As part of the practical justification, narrative inquirers consider issues of social justice and equity. We wonder, 
alongside participants how their and our experiences might be shaped differently in the future. (CLANDININ \& CAINE, 2013, p. 174)

It is in the practical justification that the social "so what" begins to take shape. We con-sider the social dimension of experience and in this way we contribute to social contexts.

The theoretical/social justification draws together these two concerns. By doing so we realize that the social informs the theoretical and the theoretical informs the social. In this justification we consider how our research shapes the methodology. What new insights do we bring to narrative inquiry? How is the methodology moved forward? In this way our inquiries help people to understand the experiences of others. We contribute to the knowl-

\section{References}

AJAYI, L. Investigating effective teaching methods for a place-based teacher preparation in a rural community. Educational Research for Policy and Practice, 13 (3), p. 251-268, 2014.

AZANO, A. The possibility of place: One teacher's use of place-based instruction for English students in a rural high school. Journal of Research in Rural Education, 26 (10), p. 26-10, 2011.

AZANO, A. Rural: The Other Neglected" R": Making Space for Place in School Libraries. Knowledge Quest, 43 (1), p. 60, 2014

BROOK, J. Placing elementary music education: a case study of a Canadian rural music program. Music Education Research, 15 (3), p. 290-303, 2013.

CLANDININ, D. J. Engaging in narrative inquiry. Walnut Creek, CA: Left Coast Press, Inc, 2013.

CLANDININ, D. J. \& CONNELLY, F. M. Narrative inquiry: experience and story in qualitative research. San Francisco, Calif.: Jossey-Bass, 2000.

CLANDININ, D. J. \& CONNELLY, F. M. Teachers' professional knowledge landscapes. New York: Teachers College Press, 1995. edge of our disciplines (teaching, medicine, social work, languages, etc.) and policy conversations.

It is evident as we showed in the section regarding our own justifications and in the above writing that the three justifications are intimately connected. While we might be able to show them in some separate manner there are many overlaps.

While we have teased out three threads for narrative inquirers to consider it is evident how intertwined our work is regarding who we are, what we inquire into, and why we conduct narrative inquiries. At the heart of a narrative inquiry is experience, both our personal, the participants', and the experience itself of conducting a narrative inquiry.

CLANDININ, D. J., \& CONNELLY, F. M. Teacher as curriculum maker. In P. W. Jackson (Ed.), Handbook of research on curriculum New York: Macmillan, 1992. p. 363-401.

CLANDININ, D. J., \& CAINE, V. Narrative Inquiry. In. TRAINOR, A. A. \& GRAUE, E. (Eds.), Reviewing qualitative research in the social sciences. London: Routledge, 2013. p. 166-179.

CLANDININ, D. J., CAINE, V., \& STEEVES, P. Composing lives in transition. London: Emerald Press, 2013.

CLANDININ, D. J., MURPHY, M. S., HUBER, J., \& MURRAY-ORR, A. Negotiating narrative inquiries: Living in a tension-filled midst. The Journal of Educational Research, 103, p. 81-90, 2010.

CLANDININ, D. J.; HUBER, J.; HUBER, M.; MURPHY, M. S.; MURRAY-ORR, A.; PEARCE, M.; \& STEEVES, P. Composing diverse identities: Narrative inquiries into the interwoven lives of children and teachers. London: Routledge, 2006.

CLANDININ, D.J. \& ROSIEK, J. Mapping a landscape of narrative inquiry: Borderland spaces and tensions. In. CLANDININ, D. J. (Ed.). Handbook of narrative inquiry: mapping methodology. Thousand Oaks, CA: 
Sage Publications, 2007. p. 35-75.

CONNELLY, F. M., \& CLANDININ, D. J. Narrative Inquiry. In GREEN, J.; CAMILLI, G. \& ELMORE, P. (Eds.). Handbook of complementary methods in education research. Mahwah, NJ: Lawrence Erlbaum, 2006. p. 477487.

CONNELLY, F. M., \& CLANDININ, D. J. (1999). Shaping a professional identity: Stories of educational practice. New York: Teachers College Press, 1999.

CONNELLY, F. M., \& CLANDININ, D. J. Teachers as curriculum planners: narratives of experience. New York, NY: Teachers College Press, 1988.

DEWEY, J. Experience and education. New York: Simon and Schuster Inc, 1938.

DEWEY, J. Experience and education. New York: Touchstone [1938], 1997.

GRUENEWALD, D. A., \& SMITH, G. A. Place-based education in the global age: Local diversity: London: Routledge, 2014.

HUBER, J., MURPHY, M. S., \& CLANDININ, D. J. Places of Curriculum Making: Narrative Inquiries Into Children's Lives in Motion. New York: Emerald Group Pub Limited. 2011.
LUGONES, M. Playfulness, World Traveling and Loving Perceptions. Hypatia, 2 (2), p. 3-19, 1987.

MURPHY, M. S., HUBER, J., \& CLANDININ, D. J. Narrative Inquiry Into Two Worlds of Curriculum Making. Learning Landscapes, 5, p. 219-236, 2012.

SCHWAB, J. J. The Practical: Translation into Curriculum. In WESTBURY, I. \& WILKOF, N. J. (Eds.), Science, curriculum, and liberal education: Selected essays. Chicago: University of Chicago Press. 1978. p. 365383.

SMYTH, J.; HATTAM, R.; WITH CANNON, J., EDWARDS, J., WILSON, N. \& WURST, S. Dropping out, drifting off, being excluded: Becoming somebody without school. New York: Peter Lang Publishing, 2004.

WAITE, S. 'Knowing your place in the world': how place and culture support and obstruct educational aims. Cambridge Journal of Education, 43 (4), p. 413433, 2013.

WENGER, E. Communities of Practcies: Learning, Meaning and Identity. Cambridge University Press, 1998.

Recebido em: 30.03.2016

Aprovado em: 01.11.2016

Dilma Mello é Mestre em Linguística Aplicada e Estudos da Linguagem pela Pontifícia Universidade Católica de São Paulo e Doutora em Linguística Aplicada e Estudos da Linguagem pela Pontifícia Universidade Católica de São Paulo, com passagem pela Universidade de Alberta-Canadá, para realização de doutorado sanduiche com bolsa CAPES (20032004) e para Pós-doutoramento com bolsa CAPES (2012-2013). Atualmente é professora Associado II da Universidade Federal de Uberlândia e líder do GPNEP (Grupo de Pesquisa Narrativa e Educação de Professores). Email: mello.dilma@ gmail.com

Universidade Federal de Uberlândia, Instituto de Letras e Lingüística. Av. João Naves de Ávila, 2121 bl U sala 1 U206 - Santa Mônica - Uberlândia, MG - Brasil CEP: 38408100

Shaun Murphy, PhD, is an Associate Professor in Curriculum Studies at the University of Saskatchewan. He was a primary schoolteacher for 20 years. Shaun co-authored Composing Diverse Identities: Narrative Inquiries into the Interwoven Lives of Children and Teachers (Routledge, 2006) and Places of Curriculum Making: Children's Lives in Motion (Emerald, 2011). His current research interests are in mathematics education, curriculum, familial curriculum making, and teacher and student identity. Email: shaun.murphy@usask.ca

Universidade de Saskatchewan

Saskatoon, SK S7N 5C5, Canadá

D. Jean Clandinin is Professor and Director of the Centre for Research for Teacher Education and Development at the University of Alberta. She is a former teacher, counselor, and psychologist. She co-authored with F. Michael Connelly four books and many chapters and articles. Their most recent book is Narrative Inquiry: Experience and Story in Qualitative Research. Jean also coauthored Composing Diverse Identities: Narrative Inquiries into the Interwoven Lives of 
Children and Teachers (Routledge, 2006) and Places of Curriculum Making: Children's Lives in Motion (Emerald, 2011). Jean is currently working on a narrative inquiry with youth and families of Aboriginal heritage as well as on a narrative inquiry with teachers who leave teaching within the first five years of teaching. She is past Vice President of Division B of AERA and is the 1993 winner of AERA's Early Career Award. She is the 1999 winner of the Canadian Education Association Whitworth Award for educational research. She was awarded the Division B Lifetime Achievement Award in 2002 from AERA. She is a 2001 winner of the Kaplan Research Achievement Award, the University of Alberta's highest award for research and a 2004 Killam Scholar at the University of Alberta. Email: jean.clandinin@ualberta.ca

Universidade de Alberta

116 St \& 85 Ave, Edmonton, AB T6G 2R3, Canadá 